\title{
Analisis Sifat Fisik dan Mekanik Papan Partikel Berbahan Dasar Sekam Padi
}

\author{
Fauziah'1), Dwiria Wahyuni*1), Boni P. Lapanporo1) \\ 1) Jurusan Fisika Fakultas Matematika dan Ilmu Pengetahuan Alam \\ Universitas Tanjungpura \\ *Email : dwiriawahyuni@physics.untan.ac.id
}

\begin{abstract}
Abstrak
Telah dilakukan pembuatan papan patikel dari sekam padi dengan menggunakan perekat urea formaldehyde (UF). Penelitian ini dilakukan untuk mengetahui sifat fisik dan mekanik pada papan partikel. Pembuatan papan partikel menggunakan bahan baku sekam kasar dan sekam halus dengan perbandingan bahan baku 60 : 40, dan penambahan perekat urea formaldehyde (UF) dengan persentase berat perekat yang digunakan adalah 18\%, 20\%, dan 22\%. Papan partikel kemudian dikempa dengan tekanan $25 \mathrm{~kg} / \mathrm{cm}^{2}$ pada suhu $140^{\circ} \mathrm{C}$ selama 8 menit. Papan partikel yang dihasilkan kemudian diuji sifat fisik dan mekaniknya menurut standar JIS A 5908-2003. Dari hasil penelitian sifat fisik yang memenuhi standar JIS A 5908-2003 yaitu kerapatan dengan nilai 0,703 g/ $\mathrm{cm}^{3}$ sampai $0,709 \mathrm{~g} / \mathrm{cm}^{3}$ dan kadar air dengan nilai 8,75\% sampai 9,92\%. Akan tetapi, sifat mekanik papan partikel tidak memenuhi standar JIS A 5908-2003. Hasil penelitian menunjukkan bahwa papan partikel dari sekam padi dapat digunakan sebagai bahan baku papan partikel.
\end{abstract}

Kata kunci : sekam padi, urea formaldehida, parafin, katalis, dan papan partikel

\section{Pendahuluan}

Padi merupakan produk utama pertanian di negara-negara agraris termasuk Indonesia. Penggilingan padi menghasilkan $72 \%$ beras, 5\% dedak, dan 20-22\% sekam (Prasad, dkk., 2001). Sekam padi merupakan produk samping yang melimpah dari hasil penggilingan padi yang selama ini hanya digunakan sebagai bahan bakar untuk pembakaran batu merah, pembakaran untuk memasak atau dibuang begitu saja. Penanganan sekam padi yang tidak tepat akan menimbulkan pencemaran terhadap lingkungan. Sekam padi mengandung 78-80\% bahan organik yang mudah menguap yaitu lignin, selulosa, dan gula. Abu sekam padi yang dihasilkan dari pembakaran sekam padi adalah sekitar 20\% (Yalqin dan Selving, 2001). Untuk mengurangi dampak terhadap lingkungan, diperlukan alternatif untuk memanfaatkan sekam padi ini. Salah satu alternatif yang bisa digunakan adalah menggunakan sekam padi sebagai bahan pembuatan papan partikel. Penggunaan sekam diharapkan dapat menjadi bahan pengganti kayu yang sampai sekarang masih mendominasi pembuatan papan partikel. Papan partikel yang dibuat dari sekam dapat menjadi substitusi kayu dimana permintaan kayu di pasaran masih cukup tinggi. Adanya substitusi kayu dengan papan partikel diharapkan dapat mengurangi tingginya penggunaan kayu untuk kebutuhan struktur dan non struktur.
Riska (2008) melakukan penelitian tentang pembuatan papan partikel dari sekam yang direbus dan menggunakan limbah plastik sebagai bahan perekatnya. Malau (2009) berhasil memanfaatkan ampas tebu untuk dijadikan papan partikel dengan menggunakan urea formaldehida sebagai bahan perekat. Pada penelitian ini digunakan cara yang berbeda yaitu dengan proses penjemuran sekam dan perekat yang digunakan dalam proses pembuatan papan partikel sekam adalah urea formaldehida. Penelitian ini dilakukan untuk mengetahui sifat fisik dan mekanik papan partikel dari sekam padi dan diharapkan pembuatan papan partikel dari sekam padi dapat bermanfaat untuk memenuhi kebutuhan papan, serta mengurangi dampak pencemaran lingkungan.

Papan partikel mempunyai beberapa kelebihan dibanding kayu asalnya yaitu papan partikel bebas dari mata kayu, pecah dan retak, selain itu ukuran dan kerapatan papan partikel dapat disesuaikan dengan kebutuhan, mempunyai sifat isotropis, serta sifat dan kualitasnya dapat diatur. Kelemahan papan partikel adalah stabilitas dimensinya yang rendah. Pengembangan tebal papan partikel sekitar 10\% hingga 25\% dari kondisi kering ke basah melebihi pengembangan kayu utuhnya serta pengembangan liniernya sampai $0,35 \%$. Pengembangan panjang dan tebal pada papan partikel ini sangat besar pengaruhnya terhadap 
pemakaian, terutama bila digunakan sebagai bahan bangunan (Haygreen dan Bowyer, 1996).

\section{Metodologi \\ Material dan Peralatan}

Sekam padi diperoleh dari penggilingan padi jalan Parit Haji Husin 2 Pontianak, sedangkan bahan lainya adalah urea formaldehyda (UF), parafin, katalis. Peralatan yang digunakan alat press hidrolik panas (Hot press), ayakan berukuran 20-25 mesh, blender, cetakan, cutter, ember plastik, kaliper, kantong plastik, kertas teflon 2 buah, lempeng alumunium 2 buah, mikrometer, neraca digital, oven, rotary blender, spray gun, timbangan.

\section{Persiapan bahan baku}

Persiapan penelitian dilakukan dengan mengeringkan sekam dengan penjemuran selama 1 hari. Sebagian sekam kering digiling kemudian diayak dengan ayakan berukuran 20 mesh. Selanjutnya partikel sekam padi dioven pada suhu $85^{\circ} \mathrm{C}$ sampai kadar airnya $5 \%$ sekitar 24 jam - 27 jam pengovenan. Setelah itu, hasilnya dimasukkan ke dalam plastik kemasan.

\section{Pembuatan papan partikel}

Pembuatan papan partikel dimulai dengan mencampur partikel sekam murni $60 \%$, sekam halus $40 \%$, perekat, parafin, dan katalis. Campuran partikel dan perekat yang telah tercampur merata dimasukkan ke dalam pencetak ukuran (30 x 30 x 1) cm kemudian dipadatkan. Campuran partikel yang telah dimasukkan ke dalam cetakan kemudian dikempa panas, namun sebelumnya, pada bagian sisi kiri dan kanan diletakkan batang besi persegi dengan panjang sisi $1 \mathrm{~cm}$ agar didapat ketebalan yang diinginkan, yaitu $1 \mathrm{~cm}$. Pengempaan dilakukan dengan menggunakan mesin kempa panas (hot press) dengan waktu kempa 8 menit, suhu kempa $140^{\circ} \mathrm{C}$ dan tekanan kempa $25 \mathrm{~kg} / \mathrm{cm}^{2}$. Kemudian papan partikel didinginkan dan dilepaskan dari cetakan lalu dilakukan pengkondisian selama 7-14 hari supaya kadar air lembaran papan partikel yang dibuat seragam pada seluruh bagian papan.

\section{Pengujian Sifat Fisik Papan Partikel}

- Uji kerapatan

Pada uji ini, contoh uji berukuran $10 \mathrm{~cm} \mathrm{x}$ $10 \mathrm{~cm}$ dalam keadaan kering udara dan kemudian diukur panjang, lebar dan tebalnya untuk menentukan volume contoh uji (panjang, lebar, tebal). Kerapatan papan partikel dihitung dengan menggunakan persamaan (1) :

$$
\mathrm{K}=\frac{B}{V}
$$

Keterangan:

$\mathrm{K}=\operatorname{Kerapatan}\left(\mathrm{g} / \mathrm{cm}^{3}\right)$;

$\mathrm{B}=$ berat kering udara $(\mathrm{g})$;

$\mathrm{V}=$ volume kering udara $(\mathrm{g})$
- Uji Kadar Air

Contoh uji berukuran $10 \mathrm{~cm}$ x $10 \mathrm{~cm}$ ditimbang berat awalnya (BA), kemudian dikeringkan dalam oven pada suhu $103 \pm 2^{\circ} \mathrm{C}$. kegiatan ini diulang sampai beratnya konstan (BKO). Contoh uji dimasukkan ke dalam desikator selama 15 menit, kemudian ditimbang, kadar air papan partikel dihitung dengan persamaan (2) :

$$
\mathrm{KA}=\frac{m 1-m 2}{m 2} \times 100 \%
$$

Keterangan :

KA = Kadar air (\%)

$m_{1} \quad$ = Massa kering udara bahan uji ( $\mathrm{g}$ )

$m_{2} \quad$ =massa kering bahan setelah dioven $(\mathrm{g})$

- Pengembangan Tebal

Sebelum diberi air, terlebih dahulu diukur ketebalan bahan uji, kemudian direndam dalam air dingin selama 24 jam. Selanjutnyan bahan uji diukur kembali tebalnya. Perhitungan sampel uji melalui pengukuran tebal sebelum perendaman air $\left(t_{1}\right)$ dan tebal setelah perendaman selama 24 $\operatorname{jam}\left(t_{2}\right)$.

$$
\mathrm{Pt}=\frac{t 2-t 1}{t 1} \times 100 \%
$$

Keterangan :

$\mathrm{PT}=$ Pengembangan tebal (\%)

$t_{1}=$ Tebal bahan uji sebelum perendaman $(\mathrm{cm})$

$t_{2}=$ Tebal bahan uji setelah perendaman $(\mathrm{cm})$

Pengujian Sifat Mekanik Papan Partikel

- Keteguhan Lentur ( MOE)

Bahan uji diukur panjang, lebar dan tebalnya, kemudian ditempatkan pada alat uji MOE. Untuk pengujian, jarak sengga yang digunakan adalah $15 \mathrm{~cm}$. Pengujian keteguhan lentur papan partikel dilakukan bersama-sama dengan pengujian modulus patah, namun yang dicatat dalam pengujian ini adalah perubahan defleksi setiap perubahan beban tertentu dengan persamaan (4) :

$$
\mathrm{MOE}=\frac{\Delta p L^{3}}{4 \Delta y b h^{3}}
$$

Keterangan :

$\mathrm{MOE}=$ modulus elastisitas $\left(\mathrm{kg} / \mathrm{cm}^{2}\right)$

$\mathrm{p} \quad=$ beban sampai batas proporsi $(\mathrm{kg})$

$\mathrm{L} \quad=$ panjang bentangan contoh uji $(\mathrm{cm})$

$\Delta \mathrm{y}=$ perubahan defleksi setiap perubahan beban $(\mathrm{cm})$

$\mathrm{b} \quad=$ lebar contoh uji $(\mathrm{cm})$

$\mathrm{h} \quad=$ tebal contoh uji $(\mathrm{cm})$

- Keteguhan patah (MOR)

Pengujian dilakukan dengan mesin uji universal dengan contoh uji berukuran $20 \mathrm{~cm} x$ $5 \mathrm{~cm}$. Jarak penyangga yang digunakan adalah $15 \mathrm{~cm}$. Nilai MOR dihitung dengan Persamaan (5) :

$$
\mathrm{MOR}=\frac{3 p L}{2 b h^{3}}
$$


Keterangan:

$\mathrm{MOR}=$ Modulus patah $\left(\mathrm{kg} / \mathrm{cm}^{2}\right)$

$\mathrm{p} \quad=$ berat beban maksimum $(\mathrm{kg})$

$\mathrm{L}=$ panjang bentangan contoh uji $(\mathrm{cm})$

$\mathrm{b} \quad=$ lebar contoh uji $(\mathrm{cm})$

$\mathrm{h} \quad=$ tebal contoh uji $(\mathrm{cm})$

\section{Hasil}

\section{Sifat Fisik Papan Partikel}

- Kerapatan

Tabel 1. Hasil pengujian kerapatan papan partikel

\begin{tabular}{ccc}
\hline No. & $\begin{array}{c}\text { Persentase } \\
\text { Berat Perekat }\end{array}$ & $\begin{array}{c}\text { Rerata Kerapatan } \\
\left(\mathrm{g} / \mathrm{cm}^{3}\right)\end{array}$ \\
\hline 1 & $18 \%$ & 0,709 \\
2 & $20 \%$ & 0,705 \\
3 & $22 \%$ & 0,703 \\
\hline
\end{tabular}

Berdasarkan hasil pengujian yang dilakukan, diperoleh nilai dari kerapatan papan partikel adalah antara $0,703 \mathrm{~g} / \mathrm{cm}^{3}$ sampai dengan $0,709 \mathrm{~g} / \mathrm{cm}^{3}$. Kerapatan tertinggi terdapat pada persentase berat perekat $18 \%$ dan yang terendah terdapat pada persentase berat perekat $22 \%$. Standar JIS A 5908-2003 mensyaratkan bahwa kerapatan papan partikel yang baik yaitu $0,5-0,9 \mathrm{~g} / \mathrm{cm}^{3}$. Secara keseluruhan kerapatan papan partikel yang dibuat melalui penelitian ini sudah sesuai dengan standar kerapatan yang ditargetkan yaitu sekitar $0,70 \mathrm{~g} / \mathrm{cm}^{3}$.

Semakin besar konsentrasi perekat yang digunakan maka nilai kerapatan papan partikel akan semakin tinggi (Sulastiningsih, 2009), akan tetapi hasil penelitian ini menunjukkan bahwa nilai kerapatan menurun karena ketebalan papan yang dibuat berbeda dari sisi tepi dan tengah papan. Sedangkan nilai kerapatan diambil pada sisi tengah papan. Hal ini berpengaruh terhadap kerapatan yang bergantung pada volume papan. Kerapatan papan juga dipengaruhi oleh bahan baku sekam padi. Kerapatan menurun dikarenakan komposisi partikel yang minim dan rongga banyak diisi oleh perekat sehingga papan mempunyai berat yang kecil dibanding dengan volume dari papan itu sendiri (Mawardi, 2009).

\section{- Kadar Air}

Kadar air merupakan sifat fisis yang ditentukan setelah melalui proses pengovenan. Kadar air menunjukkan kandungan air yang terdapat pada papan partikel ketika berada dalam keadaan kesetimbangan dengan lingkungan sekitarnya.

Hasil pengujian yang telah dilakukan menunjukkan nilai kadar air papan partikel berkisar antara $8,75 \%$ sampai 9,92\%. Nilai kadar air papan partikel yang tertinggi terdapat pada papan dengan persentase berat perekat
$22 \%$, sedangkan nilai yang terendah adalah yang terdapat pada persentase berat perekat 18\%. Untuk standar JIS A 5908-2003 pada kadar air papan partikel adalah 5\% sampai 13\%. Kadar air papan partikel pada penelitian ini dari semua perlakuan sudah sesuai dengan standar JIS A 5908-2003 sebagaimana terlihat pada Tabel 2.

Tabel 2. Hasil pengujian kadar air papan partikel

\begin{tabular}{ccc}
\hline No & $\begin{array}{c}\text { Persentase } \\
\text { Berat Perekat }\end{array}$ & $\begin{array}{c}\text { Rerata Kadar } \\
\text { Air (\%) }\end{array}$ \\
\hline 1 & $18 \%$ & 8,75 \\
2 & $20 \%$ & 9,00 \\
3 & $22 \%$ & 9,92 \\
\hline
\end{tabular}

Besarnya kadar air dalam papan partikel dipengaruhi oleh kadar air bahan baku. Kadar air sekam kasar lebih besar dari kadar air sekam halus yang telah dioven selama 24 jam pada suhu $85^{\circ} \mathrm{C}$ dengan kadar air $5 \%$. Semakin sedikit bahan baku yang digunakan maka kadar air juga semakin kecil, akan tetapi hasil penelitian ini menunjukkan bahwa nilai kadar air semakin besar. Tingginya nilai kadar air disebabkan sifat papan partikel yang bersifat higroskopis karena mengandung lignin dan selulosa, dimana semua bahan mengandung lignin dan selulosa sangat mudah menyerap dan melepaskan air (higroskopis) dan selain bahan baku yang berpengaruh terhadap tingginya kadar air papan, penggunaan perekat cair juga dapat meningkatkan kadar air papan sebesar 4\% sampai dengan 6\% (Haygreen dan Bowyer, 2003).

- Pengembangan Tebal

Tabel 3. Hasil pengujian pengembangan tebal

\begin{tabular}{ccc}
\hline No & $\begin{array}{c}\text { Persentase } \\
\text { Berat Perekat }\end{array}$ & $\begin{array}{c}\text { Rerata } \\
\text { Pengembangan } \\
\text { Tebal (\%) }\end{array}$ \\
\hline 1. & $18 \%$ & 19,4 \\
2. & $20 \%$ & 16,0 \\
3. & $22 \%$ & 13,5 \\
\hline
\end{tabular}

Hasil pengujian papan partikel yang telah dilakukan menunjukkan persentase pengembangan tebal setelah direndam selama 24 jam yang dialami oleh papan adalah 13,5\% sampai dengan 19,4\%. Pengembangan tebal tertinggi terdapat pada persentase berat perekat $18 \%$ dan pengembangan tebal yang terendah terdapat dapa persentase berat perekat $22 \%$. Pada penelitian ini, papan partikel yang dihasilkan belum memenuhi standar yang ditentukan karena melebihi standar. Untuk standar JIS A 5809-2003 pengembangan tebal papan partikel yaitu maksimal $12 \%$.

Dari hasil pengujian papan partikel pada Tabel 3, nilai pengembangan tebal yang tidak memenuhi standar diperkirakan dipengaruhi faktor jumlah sekam padi yang 
digunakan terutama sekam padi kasar. Selama penelitian diketahui bahwa pengembangan tebal terjadi karena bahan baku yang terdiri dari sekam kasar mudah mengembang. Pengembangan tebal berkaitan dengan penyerapan air oleh papan partikel. Dengan semakin tingginya serapan air, maka partikelpartikel sekam menyerap air sehingga melemahkan ikatan antar partikel dan akhirnya membuat papan partikel mengembang, artinya semakin banyak pula perubahan dimensi papan partikel yang terjadi. Jumlah sekam padi yang banyak membuat hasil pengembangan tebal menjadi semakin besar pula.

\section{Sifat Mekanik Papan Partikel}

- Modulus Elastisitas (MOE)

Tabel 4 pengujian MOE papan partikel

\begin{tabular}{ccc}
\hline No & $\begin{array}{c}\text { Persentase } \\
\text { Berat Perekat }\end{array}$ & $\begin{array}{c}\text { Rerata MOE } \\
\left(\mathrm{kg} / \mathrm{cm}^{2}\right)\end{array}$ \\
\hline 1 & $18 \%$ & $8.695,99$ \\
2 & $20 \%$ & $10.470,49$ \\
3 & $22 \%$ & $10.465,26$ \\
\hline
\end{tabular}

Tabel 4 menunjukkan bahwa nilai MOE yang diperoleh berkisar antara 8.695,99 kg/ $\mathrm{cm}^{2}$ sampai dengan $10.470,49 \mathrm{~kg} / \mathrm{cm}^{2}$. Nilai MOE yang tertinggi terdapat pada papan partikel dengan persentase berat perekat $20 \%$ dan nilai MOE yang terendah pada persentase berat perekat $18 \%$. Pada penelitian, papan partikel yang dihasilkan belum memenuhi standar JIS A 5809-2003. Standar JIS A 5809-2003 mensyaratkan MOE papan partikel yaitu 20.000 $\mathrm{kg} / \mathrm{cm}^{2}$.

Hasil pengujian menunjukkan bahwa nilai rerata MOE tertinggi pada penelitian ini adalah pada papan partikel dengan persentase berat perekat 20\%. Nilai MOE dipengaruhi oleh kandungan dan jenis bahan perekat yang digunakan, daya ikat perekat dan ukuran partikel (Maloney 1993). Berdasarkan dari hasil pengujian MOE papan partikel pada Tabel 4 diketahui bahwa faktor jumlah campuran sekam padi kasar dan halus berpengaruh terhadap MOE papan partikel yang dihasilkan. Hal ini disebabkan karena saat pencampuran perekat pada bahan baku kurang merata, dimana semakin bertambah persentase berat perekat maka bahan baku juga berkurang. Penambahan sekam kasar pada papan partikel menyebabkan papan partikel menjadi lebih kaku, sehingga tidak elastis.

- Modulus Patah (MOR)

\begin{tabular}{|c|c|c|}
\hline No & $\begin{array}{c}\text { Persentase } \\
\text { Berat Perekat }\end{array}$ & $\begin{array}{c}\text { Rerata MOR } \\
\left(\mathrm{kg} / \mathrm{cm}^{2}\right)\end{array}$ \\
\hline 1. & $18 \%$ & 56,102 \\
\hline 2. & $20 \%$ & 65,567 \\
\hline 3. & $22 \%$ & 76,682 \\
\hline
\end{tabular}

Hasil pengujian keteguhan patah dapat dilihat pada Tabel 5. Nilai MOR papan partikel yang diperoleh berkisar antara 56,102 kg/ $\mathrm{cm}^{2}$ dan $76,682 \mathrm{~kg} / \mathrm{cm}^{2}$. Nilai MOR yang tertinggi terdapat pada papan partikel dengan persentase berat perekat $22 \%$ dan yang terendah terdapat pada persentase berat perekat $18 \%$. Standar JIS A 5809-2003 mensyaratkan nilai MOR papan partikel yaitu $82 \mathrm{~kg} / \mathrm{cm}^{2}$ sampai $184 \mathrm{~kg} / \mathrm{cm}^{2}$. Pada penelitian ini nilai MOR papan partikel belum memenuhi standar JIS A 5809-2003, hal ini diperkirakan karena partikel tersebut tidak saling mengisi dan tidak saling mengikat antara satu partikel dengan partikel lainnya, sehingga kekuatan patah papan tersebut rendah.

Maloney (1993) menyatakan bahwa nilai MOR dipengaruhi oleh kandungan dan jenis perekat yang digunakan, daya ikat perekat, dan ukuran partikel. Oleh karena komposisi bahan yang menggunakan sekam padi kasar memiliki kelemahan, yaitu sekam padi kasar memiliki rongga yang besar antar partikel tersebut sehingga kekuatan antar partikel lemah.

\section{Kesimpulan}

Dari hasil penelitian yang telah dilakukan dapat diambil kesimpulan yaitu sifat fisis papan partikel sekam padi pada sifat kerapatan 0,703 $\mathrm{gram} / \mathrm{cm}^{3}$ sampai $0,709 \mathrm{gram} / \mathrm{cm}^{3}$ dan kadar air 8,75\% sampai 9,92\% memenuhi standar JIS A 5908-2003. Sedangkan, sifat mekanik papan partikel sekam padi tidak memenuhi standar JIS A 5908-2003.

\section{Daftar Pustaka}

Hasni Rizka, 2008, Pembuatan Papan Partikel dari Limbah Plastik dan Sekam. Institut Pertanian Bogor.

Haygreen, J.G., dan Bowyer, J.L., 1996, Hasil Hutan dan Ilmu Kayu : Suatu Pengantar. Sujipto, A.H, penerjemah; Yogyakarta: Gajah Mada University Press. Terjemahan dari : Forest Product and Wood Science: An Introduction.

Maloney, T.M., 1993. Modern Particle Board and Dry Process Fiberboard Manufacturing. Inc Sanfransisco: Miller Freeman.

Sulastiningsih IM, Novitasari, Turoso A. 2009. Pengaruh Kadar Perekat Terhadap Sifat Papan Partikel Bambu. Bogor. Jurnal Pusat Peneltian dan Pengembangan Hasil Hutan. 